\title{
Drug resistance in airborne bacteria isolated from waste management and wastewater treatment plants in Olsztyn
}

\author{
Jacek Potorski ${ }^{1,{ }^{*}}$, Izabela Koniuszewska $^{1}$, Matgorzata Czatzkowska $^{1}$, and Monika Harnisz ${ }^{1}$ \\ ${ }^{1}$ Department of Environmental Microbiology, University of Warmia and Mazury in Olsztyn, Poland
}

\begin{abstract}
Wastewater treatment plants (WWTPs) and municipal waste management plants (MWMPs) emit bioaerosols containing potentially pathogenic biological components which post a threat for human health. Microbiological monitoring supports evaluations of the antibiotic resistance (AR) of airborne microorganisms and the relevant health risks. The aim of this study was to analyze the microbiological quality of air sampled in a WWTP and MWMP in Olsztyn based on total bacterial counts, the presence of bacteria resistant to three antibiotic classes (betalactams, tetracyclines and chloramphenicol) and genes encoding resistance to these antibiotics (bla $\mathrm{TEM}_{\mathrm{T}}$ bla $\mathrm{SHV}_{\mathrm{S}}, \operatorname{bla}_{\mathrm{CMY}-2}, \operatorname{bla}_{\mathrm{AmpC}}, \operatorname{tet}(\mathrm{M}), \operatorname{tet}(\mathrm{A})$, $\operatorname{tet}(\mathrm{X}), \operatorname{tet}(\mathrm{B}), c m l A$, floR, $\operatorname{fex} A, f e x B$ and $\operatorname{cat} A 1)$. Bacterial counts were higher in air samples collected from the MWMP $\left(\sim 10^{4} \mathrm{CFU} / \mathrm{m}^{3}\right)$ than from the WWTP $\left(10^{1}-10^{3} \mathrm{CFU} / \mathrm{m}^{3}\right)$. A similar trend was noted in the counts of antibiotic resistant bacteria (ARB). The abundance of ARB did not exceed $1.7 \times 10^{2} \mathrm{CFU} / \mathrm{m}^{3}$ in WWTP samples, but was higher at up to $4.2 \times 10^{3} \mathrm{CFU} / \mathrm{m}^{3}$ in MWMP samples. Bacteria resistant to doxycycline were least prevalent in the analyzed ARB. In the group of 49 tested bacterial strains, 44 harbored at least one of the analyzed antibiotic resistance genes (ARGs). A comparison of ARGs in all bacterial strains isolated from WWTP and MWMP air samples revealed the highest diversity and prevalence of ARGs in the samples collected in the mechanical segment of the waste processing line in MWMP and the biological segment of the wastewater processing line in WWTP. The results of this study point to high microbiological contamination of air in MWMPs and WWTPs which are reservoirs of ARB and ARGs and potential sources of AR.
\end{abstract}

\section{Introduction}

Wastewater treatment plants (WWTPs) and municipal waste management plants (MWMPs) emit odors and biological aerosols which are potential sources of microbiological contamination in atmospheric air [1-3]. Plant employees are exposed to class 2 biological factors (Regulation of the Minister of Health of 2005) that are potentially hazardous for human health [4]. Bioaerosols contain bacteria, viruses, fungi, yeasts and yeast-like fungi.

\footnotetext{
* Corresponding author: jacek.potorski@uwm.edu.pl
} 
Potentially pathogenic airborne microorganisms can cause many infectious diseases in humans and animals $[5,6]$. The concentration and range of bioaerosol emissions are determined by the size of the processing plant, the applied technology and conditions in every segment of the plant (mechanical/biological waste treatment). Weather conditions, including strong winds, also contribute to the spread of airborne microorganisms $[3,6]$. The type and reach of processing plants environmental impact is influenced by initial microbial counts in solid waste and wastewater, microbial growth stages, the applied processing technology, weather and environmental conditions [7]. According to the invalid, but the only available microbial contamination reference standards for atmospheric air which expired in 2015 [8], bacterial counts of $10^{3} \mathrm{CFU} / \mathrm{m}^{3}$ are indicative of strongly contaminated air. Highly contaminated air can also contain antibiotic resistant bacteria (ARB) which are transferred from processed waste in plants, many of which are large open areas.

Antibiotic resistant bacteria (ARB) pose a significant threat to public health because they progressively less sensitive to pharmacological treatment. These pathogens have highly specialized molecular mechanisms which enable bacteria to rapidly adapt to and proliferate in environments with high antibiotic concentrations, such as WWTPs and MWMPs where various sources of waste are mixed. Growing levels of antibiotic resistance and the increasing biodiversity of antibiotic resistance genes (ARGs) pose a considerable problem. Microbiological monitoring systems in WWTPs and MWMPs should also be able to detect ARB strains [9-11].

The aim of this study was to analyze the microbiological quality of air sampled from a WWTP and a MWMP in Olsztyn based on total microbial counts, the presence of bacteria resistant to three antibiotic classes (beta-lactams, tetracyclines and chloramphenicol) and genes encoding resistance to these antibiotics (bla $a_{\mathrm{TEM}}$, bla $_{\mathrm{SHV}}$, bla $_{\mathrm{CMY}-2}$, bla $a_{\mathrm{AmpC}}, \operatorname{tet}(\mathrm{M})$, tet(A), tet(X), tet(B), cmlA, floR, fexA, fexB and catAl).

\section{Sampling sites}

Air was sampled from the Municipal Waste Management Plant (MWMP) in Olsztyn and the Łyna Municipal Wastewater Treatment Plant (WWTP) in Olsztyn. In both plants, air samples were collected in the mechanical and biological segments of solid waste and wastewater processing lines.

\section{Materials and methods}

\subsection{Determination of total bacterial counts and counts of drug resistant bacteria}

Air samples were collected by aspiration with the MAS-100 Eco air sampler (Merck). The total counts of airborne bacteria were determined on Miller's LB agar (A\&A Biotechnology) with peptone. Antibiotic resistant strains were isolated on Miller's LB Agar (A\&A Biotechnology) with ampicillin $(8 \mathrm{mg} / \mathrm{L})$, doxycycline $(2 \mathrm{mg} / \mathrm{L})$ or chloramphenicol $(8 \mathrm{mg} / \mathrm{L})$. Antibiotic concentrations in the culture medium were determined based on EUCAST 2018 guidelines [12]. Air samples were collected once in the summer of 2018. The results were presented as $\mathrm{CFU} / \mathrm{m}^{3}$.

\subsection{Isolation and amplification of dsDNA}

Up to five morphologically different bacterial colonies were isolated from each ARB culture. Every culture was suspended in $0.5 \mathrm{~mL}$ of distilled water, and genomic DNA was 
isolated from 22 ampicillin-resistant strains, 15 chloramphenicol-resistant strains and 12 doxycycline-resistant strains. DNA was isolated by thermal lysis [14]. The presence of genes encoding resistance to $\beta$-lactams (bla $\left.a_{\mathrm{TEM}}, b l a_{\mathrm{SHV}}, b l a_{\mathrm{AmpC}}, b l a_{\mathrm{CMY}-2}\right)$, tetracyclines $(\operatorname{tet}(\mathrm{A}), \operatorname{tet}(\mathrm{B}), \operatorname{tet}(\mathrm{M}), \operatorname{tet}(\mathrm{X}))$, chloramphenicols and florfenicols $(\mathrm{cmlA}, f l o R, f e x A, f \operatorname{exB}$, catAl) was determined by standard PCR, according to previous described parameters [15-21].

\section{Results and discussion}

\subsection{Determination of microbiological air quality based on total bacterial counts and the counts of drug resistant bacteria}

The environmental impacts of waste and wastewater treatment plants are determined by biological factors and local conditions, including initial microbial counts in solid waste and wastewater, bacterial growth stages, the applied processing technology, weather and environmental conditions [22]. In this study, the total bacterial counts were lowest $\left(8.75 \times 10^{1} \mathrm{CFU} / \mathrm{m}^{3}\right)$ in air samples collected in the mechanical segment of the WWTP and highest $\left(4.51 \times 10^{4} \mathrm{CFU} / \mathrm{m}^{3}\right)$ in air samples collected in the biological segment of the MWMP. Total bacterial counts were 24-times higher in air samples from the MWMP than from the WWTP. Air samples from the mechanical segments of both plants were more highly contaminated than the samples from biological segments. The counts of all analyzed microbial groups in air samples from the evaluated sites are presented in Figure 1.

In a study by Korzeniewska et al. [1], the counts of heterotrophic mesophilic bacteria in untreated wastewater ranged from $10^{5}$ to $10^{7} \mathrm{CFU} / \mathrm{mL}$. In the work of Osińska et al. [23], the average total bacterial counts were determined at $10^{7} \mathrm{CFU} / \mathrm{mL}$ in untreated sewage and at $10^{4}$ to $10^{5} \mathrm{CFU} / \mathrm{mL}$ in treated sewage. WWTPs can emit bioaerosols which contribute to the contamination of atmospheric air and pose a public health risk [24]. The microbial contamination of air in the WWTP evaluated by Vítězová et al. [25] ranged from $10^{1}$ to $10^{4} \mathrm{CFU} / \mathrm{m}^{3}$ for psychrophilic bacteria and from $10^{1}$ to $10^{4} \mathrm{CFU} / \mathrm{m}^{3}$ for mesophilic bacteria. Air contamination was highest in the proximity of the activated sludge chamber, dried sludge storage and the mechanical segment of the wastewater treatment line. In general, aeration chambers in WWTPs are most exposed to biological aerosols [26], but in this study, total bacterial counts were 35-times higher in the mechanical than in the biological segment of the wastewater processing line.

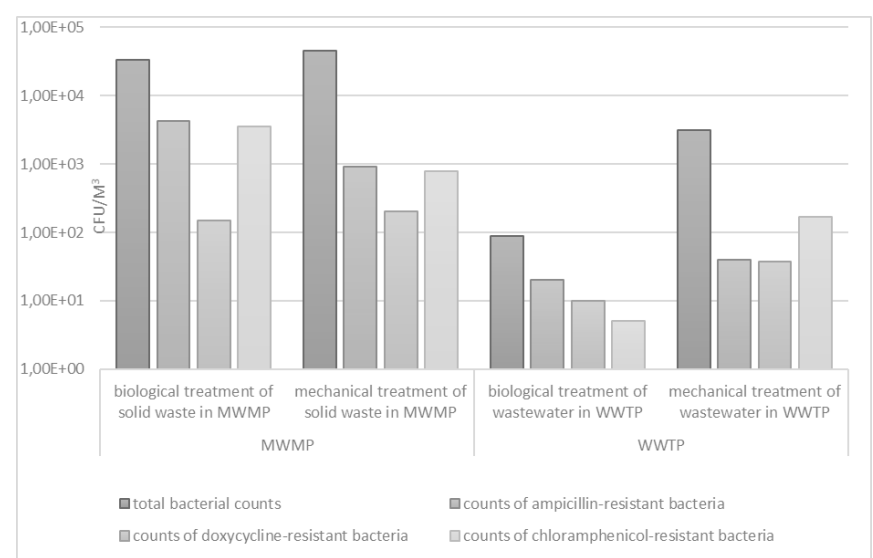


Fig. 1. Counts of all analyzed microbial groups in air samples from the evaluated sites.

Breza-Boruta [27] analyzed the microbiological quality of bioaerosols in municipal waste management plants and reported the highest total bacterial counts in the waste sorting station $\left(10^{4} \mathrm{CFU} / \mathrm{m}^{3}\right)$. In the current study, the total counts of airborne bacteria also approximated $10^{4} \mathrm{CFU} / \mathrm{m}^{3}$ in the mechanical and biological segments of the MWMP in Olsztyn. Chmielowiec-Korzeniowska et al. [28] determined total bacterial counts at $10^{6} \mathrm{CFU} / \mathrm{m}^{3}$ in a study evaluating the microbiological contamination of air in the vicinity of an animal waste management plant.

At present, there are no valid microbiological contamination standards for atmospheric air in Poland. However, in view of the standards that had expired in 2015 [8], air samples collected from the MWMP and from the mechanical segment of the WWTP were characterized by high levels of microbial contamination.

The counts of ampicillin-resistant bacteria were highest in the biological segment of the MWMP $\left(4.2 \times 10^{3} \mathrm{CFU} / \mathrm{m}^{3}\right)$ and lowest in the biological segment of the WWTP $\left(2 \times 10^{1} \mathrm{CFU} / \mathrm{m}^{3}\right)$. The counts of ampicillin-resistant bacteria were twice higher in the mechanical segment than in the biological segment of the WWTP. In the MWMP, the counts of ampicillin-resistant bacteria were 4-times higher in the biological segment than in the mechanical segment of the waste processing line.

The counts of doxycycline-resistant bacteria were lowest in the biological segment of the WWTP $\left(1 \times 10^{1} \mathrm{CFU} / \mathrm{m}^{3}\right)$ and highest in the mechanical segment of the MWMP $\left(2 \times 10^{2} \mathrm{CFU} / \mathrm{m}^{3}\right)$. Air contamination with doxycycline-resistant bacteria was higher in the mechanical segments of both analyzed plants. Odeyemi [29] evaluated the microbiological contamination of air near a landfill site in Nigeria and reported that $95.9 \%$ of all isolated bacteria were resistant to amoxicillin (amoxicillin and ampicillin belong to the group aminopenicillin antibiotics), whereas $84.6 \%$ of the isolated strains were resistant to tetracyclines. In a study by Reinthaler et al. [30], E. coli isolated from wastewater, a source of toxic bioaerosols, were most frequently resistant to penicillins, including ampicillin $(18 \%)$, as well as tetracyclines $(57 \%)$.

In the present study, the counts of chloramphenicol-resistant bacteria were highest in the biological segment of the MWMP $\left(3.5 \times 10^{3} \mathrm{CFU} / \mathrm{m}^{3}\right)$ and lowest in the biological segment of the WWTP. In the MWMP, the counts of chloramphenicol-resistant bacteria were more than 4-times higher in the biological segment than in the mechanical segment of the processing line. In the WWTP, the prevalence of this microbial group was more than 30-times higher in air samples collected from the mechanical segment.

Total microbial counts were highest in the mechanical segments of both analyzed plants. Published data are consistent only with the results noted in the MWMP.

\subsection{Drug resistance genes in the isolated bacterial strains}

The bacterial strains isolated from air samples collected in the MWMP and the WWTP harbored mainly genes encoding resistance to tetracyclines. The percentage of genes responsible for resistance to beta-lactams, chloramphenicol and florfenicol was lower. None of the bacteria isolated from the WWTP or the MWMP harbored the $f \operatorname{ex} B$ gene encoding resistance to florfenicol. A comparison of all airborne bacteria isolated from both plants revealed the highest prevalence of antibiotic resistance genes in the strains isolated from the MWMP (Fig. 2). 


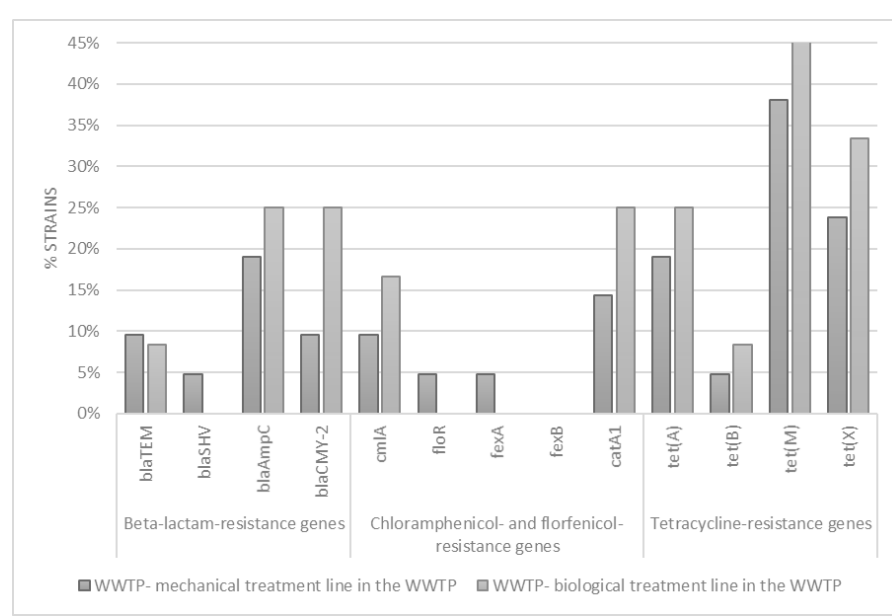

Fig. 2. Prevalence of antibiotic resistance genes [\%] in airborne bacteria isolated from the MWMP and the WWTP.

The prevalence of ARGs was also compared in 24 bacterial strains isolated from air in the mechanical and biological segments of the WWTP. The strains isolated from the biological segment of the WWTP were characterized by the highest prevalence of ARGs, and 8 out of the 9 isolated strains harbored at least 2 genes encoding resistance to antibiotics, mostly tetracyclines (data not shown). Interestingly, $\operatorname{tet}(\mathrm{M})$ was most prevalent gene in wastewater, whereas in a study of the Olsztyn WWTP conducted by Harnisz et al. [14], the most ubiquitous gene was tet(A). However, Zhang and Zhang [31] reported that both genes were most prevalent in a WWTP. Genes encoding resistance to beta-lactams and chloramphenicol were also noted in our study. Around $25 \%$ of the tested isolates harbored both $b l a_{\mathrm{AmpC}}$ and $b l a_{\mathrm{CMY}-2}$ genes which are responsible for resistance to all beta-lactams, excluding fourth-generation drugs and monobactams, which poses a significant threat for public health.

All of the 15 bacterial strains isolated from the mechanical segment of the WWTP harbored at least one ARG. This part of the WWTP was colonized by significantly fewer bacterial strains with ARGs than the biological segment. Most of the isolated strains harbored genes encoding resistance to tetracyclines and beta-lactams, but their prevalence was somewhat lower than in the biological segment of the plant. The $\mathrm{cmlA}$ gene was observed in isolated cases. None of the isolated strains harbored floR, fexA and $f e x B$ genes which encode resistance to florfenicol (Fig. 3).

A comparison of 24 airborne bacterial strains isolated from the mechanical and biological segments of the MWMP (Fig. 3) revealed a significantly higher prevalence of ARGs in the strains isolated from mechanical part of the plant. The most prevalent ARGs in the strains from the mechanical segment encoded resistance to tetracyclines. Genes responsible for resistance to tetracyclines were also most prevalent in the biological segment of the MWMP. The lower prevalence of ARGs in the strains isolated from the biological part of the plant could be attributed to the type of processed waste and the design of the waste processing line. Similar results were reported by Li et al., McEachran et al. and Xie et al. who identified ARGs in airborne bacteria isolated from WWTPs in urban and rural areas, including tetracycline resistance genes $(\operatorname{tet}(\mathrm{A}), \operatorname{tet}(\mathrm{C}), \operatorname{tet}(\mathrm{M}), \operatorname{tet}(\mathrm{O}), \operatorname{tet}(\mathrm{Q})$, $\operatorname{tet}(\mathrm{W}), \operatorname{tet}(\mathrm{B}), \operatorname{tet}(\mathrm{L}))$ [32-34]. In our study, the isolates from the mechanical part of the MWMP also harbored genes encoding resistance to beta-lactams and chloramphenicol. It should be noted that more than $35 \%$ of the isolated strains harbored the bla $a_{\mathrm{AmpC}}$ gene which is responsible for resistance to broad-spectrum beta-lactams that are widely used in clinical practice. Bacteria with mutations in regulator genes are able to produce AmpC beta-lactamases in the absence of an antibiotic inductor. The removal of the mechanism 
which represses the production of the AmpC enzyme is referred to as derepression. Isolates with derepressed AmpC become resistant to all beta-lactams, including all penicillins, cephalosporins (excluding fourth-generation drugs) and monobactams, and they are not sensitive or are largely insensitive to beta-lactamase inhibitors: clavulanic acid, sulbactam and tazobactam. This process has a tremendous impact on the clinical environment because it drives the search for new and stronger antibiotics. bla $a_{\mathrm{AmpC}}$ genes are transferred by mobile genetic elements (ISEcp1, ISCR1, IS26) in the genomes of bacteria such as $C$. freundii, Enterobacter spp. and M. morganii. Enzyme CMY-2 is a derivative of enzyme AmpC. Beta-lactamases of the CMY-2 family are the most ubiquitous derivatives of AmpC in C. freundii [35-36]. In the present study, the bla $a_{\mathrm{CMY}-2}$ gene was noted in more than $20 \%$ of the strains isolated from the mechanical segment of the MWMP, whereas the bla gene was detected in more than $10 \%$ of the tested isolates. The bla $a_{\mathrm{SHV}}$ gene was not identified in any of the analyzed strains. In a study by Li et al. (2018), genes encoding resistance to beta-lactams were highly prevalent in airborne bacteria sampled from a rural area, and $b l a_{\text {TEM }}$ was most frequently noted. The above authors concluded that airborne ARGs contributed to the emergence of new bacterial genotypes. They demonstrated that urban air was highly contaminated with ARGs which pose a serious threat to public health [32]. Considerable air pollution in the mechanical segment of the MWMP could be attributed to high proportions of organic matter in the processed waste, which offers an ideal environment for microbial growth and development. Contaminated air is released outside the MWMP, and ARB and ARGs are transferred to urban areas. Airborne pollutants and microorganisms can overcome geographic barriers, and this mode of transmission significantly contributes to the spread of ARB and ARGs across large distances [33, 34]. The results of this study confirm that airborne transmission of ARGs poses a threat in urban areas and that air quality standards should be revised to protect public health.

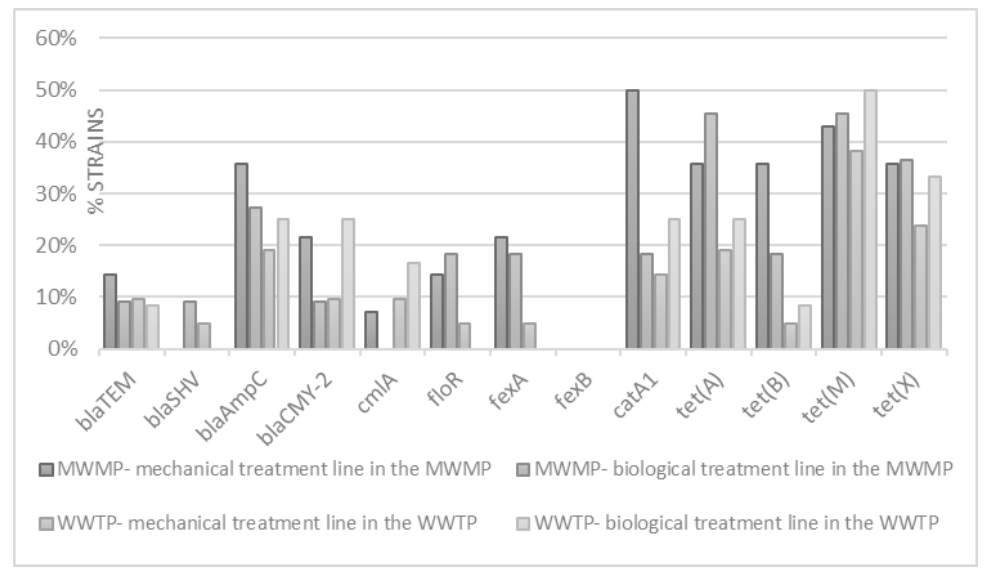

Fig. 3. Prevalence of antibiotic resistance genes [\%] in airborne bacteria isolated from the mechanical and biological segments of the WWTP and MWMP.

\section{Conclusions}

This study demonstrated that WWTPs and MWMPs are reservoirs of airborne ARB and ARGs. Antibiotic resistance genes were most diverse in the mechanical part of the MWMP and the biological segment of the WWTP in Olsztyn. In both plants, employees who come into contact with bioaerosols should handle contaminated waste and wastewater with 
utmost caution, should strictly observe occupational health and safety regulations and wear protective equipment and clothing.

This project was funded by a Student Grant awarded by the Rector of the University of Warmia and Mazury in Olsztyn.

\section{References}

1. E. Korzeniewska, Z. Filipkowska, A. Gotkowska-Płachta, W. Janczukowicz, B. Dixon, M. Czułowska, Water Res. 43 (2009)

2. E. Korzeniewska, Front Biosci. (Schol Ed) 1, 3 (2011)

3. E. Korzeniewska, M. Harnisz, J. Environ. Manage. 128 (2013)

4. Regulation of the Minister of Health of 22 April 2005 on biological factors that are hazardous for health in the work environment and health protection measures for employees who are exposed to hazardous factors in the work environment; J. Law 81 (2005)

5. R. I. Aminov, Environ. Microbiol. 11 (2009)

6. M. Szyłak-Szydłowski, A. Kulig, E. Miaśkiewicz-Pęska, Int. Biodeter. Biodegr. 115 (2016)

7. O. Golovko, V. Kumar, G. Fedorova, T. Randak, R. Grabic, Chemosphere 111 (2014)

8. PN-89/Z-04111/02 (2002) Air quality protection. Microbiological analyses. Determination of bacterial counts in atmospheric air (emission) sampled by aspiration and sedimentation

9. F. Barancheshme, M. Munir, Front Microbiol. 8 (2018)

10. M. N. Alekshun, S. B. Levy, Cell 128, 6 (2007)

11. K. Yoo, T. L. Lee, E. J. Choi, J. Yang, S. K. Shukla, S. Hwang, J. Park, J. Environ. Sci. 51 (2017)

12. EUCAST (2014) European Committee on antimicrobial susceptibility testing. Breakpoints tables for interpretation of MICs and zones diameters. Version 4.0. http://www.eucast.org

13. M. Gołofit-Szymczak, J. Skowroń, Bezp. Pr. Nauk Prakt. 3 (2005)

14. M. Harnisz, E. Korzeniewska, S. Ciesielski, I. Gołaś, Sci. Total Environ. 505 (2015)

15. J. Kim, S. Jeon, H. Rhie, B. Lee, M. Park, H. Lee, J. Lee, S. Kim, J. Infect. Chemother. 41, 3 (2009)

16. E. Ruppé, S. Hem, S. Lath, V. Gautier, F. Ariey, J. Sarthou, D. Monchy, G. Arlet, Emerg. Infect. 15, 5 (2009)

17. J. Li, B. Shao, J. Shen, S. Wang, Y. Wu, Environ. Sci. Technol. 47, 6 (2013)

18. H. Maidhof, B. Guerra, S. Abbas, H. M. Elsheikha, T. S. Whittam, L. Beutin, Appl. Environ. Microbiol. 68 (2002)

19. M. Nawaz, K. Sung, S. A. Khan, A. A. Khan, R. Steele, Appl. Environ. Microbiol. 72 (2006)

20. L. K. Ng, I. Martin, M. Alfa, M. Mulvey, Mol Cell Probes 15 (2001)

21. Z. Eitel, J. Soki, E. Urban, E. Nagy, Anaerobe 21 (2013)

22. N. Patentalakis, A. Pantidou, N. Kalogerakis, Water Air Soil Pollut. 8 (2008)

23. A. Osińska, E. Korzeniewska, M. Harnisz, S. Niestępski, E3S Web Conf. 17 (2017) 
24. L. Fracchia, S. Pietronave, M. Rinaldi, M. G. Martinotti, Water Res. 40 (2006)

25. M. Vítězová, T. Vítěz, H. Mlejnková, T. Lošák, Acta Univ. Agric. Silvic Mendel Brun. LX 3 (2012)

26. Z. Filipkowska, W. Janczukowicz, M. Krzemieniewski, J. Pesta Biul. Nauk UWM 15, 217 (2002)

27. B. Breza-Boruta, Ecol. Chem. Eng. A 19, 8 (2012)

28. A. Chmielowiec-Korzeniowska, L. Tymczyna, A. Drabik, Ł. Krzosek, Ann. Agric. Environ. Med. 23, 1 (2016)

29. A. T. Odeyemi, Microbiol. Res. 2, 2 (2012)

30. F. F. Reinthaler, J. Posch, G. Feierl, G. Wust, D. Haas, G. Ruckenbauer, F. Mascher, E. Marth, Water Res. 37 (2003)

31. X. Zhang, T. Zhang, Environ. Sci. Technol. 45, 7 (2011)

32. J. Li, J. Cao, Y. Zhu, Q. Chen, F. Shen, Y. Wu, S. Xu, H. Fan, G. Da, R. Huang, J. Wang, A. Lorelei de Jesus, L. Morawska, C. K. Chan, J. Peccia, M. Yao, Environ. Sci. Technol. 52, 19 (2018)

33. A. D. McEachran, B. R. Blackwell, J. D. Hanson, K. J. Wooten, G. D. Mayer, S. B. Cox, P. N. Smith, Environ. Health Perspect. 123 (2015)

34. J. Xie, L. Jin, X. Luo, Z. Zhao, X. Li, Environ. Sci. Technol. Lett. 5 (2018)

35. M. Barlow, B. G. Hall, Agents Chemother. 46 (2002)

36. K. Bush, J. F. Fisher, Ann. Rev. Microbiol. 65 (2011) 